\title{
Moderat dan Puritan Dalam Islam: Telaah Metode Hermeneutika Khaled M. Abou El-Fadl
}

\author{
Dian Suhandary \\ UIN Sunan Kalijaga Yogyakarta \\ diansuhandary@yahoo.com
}

\begin{abstract}
Muslims should be a means of manifesting God's grace and compassion for fellow beings. Unfortunately, messages containing humanist, tolerant, and democratic values behind the sacred texts have been taken away by groups in the name of "God's representatives" on earth. As a result, the arbitrary action behind the name of religion is still a problem. Abou El Fadl mapped two major schools within Islam, namely Puritanism and Moderatism. This research will present how Hermeneutika Khaled M. Abou El Fadl's thought towards puritanism and moderateism in Islam? This research belongs to the library research, the course of this research researchers used a descriptive analysis method. Hermeneutics Abou El-Fadl can be called 'negotiative hermeneutics. According to him, meaning must be the result of interaction between the author, the text, and the reader, where there must be a balance (balancing) and the negotiation process between the three parties, and one of the parties must not dominate the process of determining meaning. In addition, Abou El Fadl implicitly contains Gadamerian spirit who reads the text subjectively, the implication of all interpretations is not final but relative.
\end{abstract}

Keywords: Moderat, Puritan, Hermeneutic, Khaled M. Abou El-Fadl

\footnotetext{
Abstrak: Umat Islam semestinya menjadi sarana perwujudan rahmat dan kasih sayang Tuhan bagi sesama makhluk. Sayangnya, pesan yang mengandung nilai-nilai humanis, toleran, dan demokrasi dibalik teks-teks suci tersebut telah dirampas oleh kelompok yang
} 
mengatasnamakan "wakil Tuhan"dibumi. Akibatnya, tindakan kesewenang-wenangan di balik nama agama masih menjadi persoalan. Abou El Fadl memetakan dua aliran besar di dalam Islam yaitu Puritanisme dan moderatisme. Penelitian ini akan mengetengahkan bagaimana pemikiran Hermeneutika Khaled M. Abou El Fadl terhadap aliran puritanisme dan moderatisme dalam Islam? Penelitian ini tergolong dalam penelitian pustaka, jalannya penelitian ini peneliti menggunakan metode deskriptif analisis. Hermeneutika Abou El-Fadl dapat disebut 'hermeneutika negosiatif'. Menurutnya, makna harus merupakan hasil interaksi antara pengarang, teks, dan pembaca, di mana harus ada keseimbangan (balancing) dan proses negosiasi antara ketiga pihak, serta salah satu pihak tidak boleh mendominasi dalam proses penetapan makna. Selain itu, Abou El Fadl secara implisit mengandung semangat Gadamerian yang membaca teks secara subjektif, implikasinya seluruh interpretasi tidaklah bersifat final namun relatif.

Kata kunci: Moderat, Puritan, Hermenetik, Khaled M. Abou El-Fadl

\section{A. Pendahuluan}

Salah satu wacana yang berkembang saat ini adalah persoalan otoritarianisme. Secara umum otoritarianisme dipahami sebagai tindakan mengunci kehendak Tuhan atau kehendak teks dalam sebuah penetapan tertentu, dan kemudian menyajikan penetapan tersebut sebagai suatu yang pasti, absolut, dan menentukan. Merebaknya bentuk otoritarianisme seperti inilah dalam bahasa Prof. Amin Abdullah digambarkan sebagai "penggunaan kekuasaan Tuhan" (author) untuk membenarkan tindakan sewenang-wenang pembaca (reader) dalam memahami dan menginterpretasikan teks. ${ }^{1}$

Dalam bukunya "Speaking in God's Name: Islamic Law, Authority, and Women", Khaled menjelaskan bahwa otoritarianisme merupakan pengabaian terhadap realitas ontologis Tuhan dan pengambilalihan Tuhan oleh wakil Tuhan sehingga wakil tersebut secara efektif kemudian mengaju kepada dirinya sendiri. Tindakan demikian berimplikasi pada penolakan integritas petunujuk teks dengan menutup kemungkinan bagi petunjuk-petunjuk tersebut untuk

${ }^{1}$ Amin Abdullah, "Pendekatan Hermeneutik dalam Studi Fatwa-fatwa Keagamaan" dalam pengantar buku Khaled M. Abou el Fadel, Atas Nama Tuhan: dari Fiqih Otoriter ke Fiqih Otoritatif, terj. Cecep Lukman Yasin, (Jakarta: PT Serambi Ilmu Semesta, 2004), h. viii. 
mengungkapkan dirinya sendiri, dan menghalangi perkembangan dan evolusi makna komunitas interpretasi. ${ }^{2}$

Khaled Abou el-Fadl adalah seorang pemikir Islam kontemporer dari Kuwait, ia dibesarkan dengan suasana sosial yang tidak menentu, baik karena pergolakan politik-perang, teror dan ancaman yang mewarnai hari-harinya di masa anak-anak hingga remaja. Pergolakan sosial-politik tersebut membuatnya gelisah melihat masa depan, hingga akhirnya dia bergabung dengan kelompok Wahabisme, yang ia anggap dapat menawarkan solusi, ia sangat tekun dan taat pada ajaran teologi dan moralitas yang kaku, yang diajarkan oleh faham Wahabi, pemahaman yang kaku mengenai Islam ini ia coba paksakan kepada orang lain dan bahkan kelurganya sendiri, hingga ia pernah merusak kaset musik milik kakak perempuannya, dan pernah menganggap kedua orang tuanya telah keluar dari Islam (kafir), karena aktivitas kehidupan mereka tidak sesuai dengan apa yang ia pahami bersama kaum Wahabi yang lain. Akan tetapi dalam perjalanannya pemikirannya mengalami pergeseran, dari seorang fundamentalis menuju seorang pecinta demokrasi. Hal itu, tampaknya ia alami ketika ia belajar di sekolah menengah dan setelah ayahnya menantangnya untuk menjadi seorang sarjana hukum Islam.

Penulis menemukan beberapa karya yang mengangkat pemikiran Khaled Abou El-Fadl seagai pembahasan, diantaranya: karya Ali Hasan Siswanto, dalam tulisannya yang berjudul "Hermeneutika Negosiatif Khaled Abou El-Fadl; Menjunjung Otoritas Teks Sekaligus Membatasi Otoritarianisme”. Pada artikel tersebut Menyimpulkan bahwa untuk menghindari pemberangusan teks oleh para penafsir otoriter, Abou El-Fadl merasa perlu untuk menjunjung otoritas teks (the authoritativeness of the text) dan pada sisi lain, sekaligus membatasi otoritarianisme pembaca (authoritarianism of the reader) sehingga melahirkan penafsiran yang bertanggung jawab dengan memenuhi lima prasyarat, diantaranya kejujuran (honesty), kesungguhan (diligence), kemenyeluruhan

${ }^{2}$ Khaled M. Abou Fadl, Atas Nama Tuhan: Dari Fikih Otoriter ke Fikih Otoritatif, h. 205. 
(comprehensiveness), rasionalitas (reasonableness), dan pengendalian diri (self- restraint). ${ }^{3}$

Selanjutnya Raisul, "Pemikiran Hukum Islam Khaled Abou El Fadl". Dalam artikel ini peneliti mengangkat pemikiran Khalid Abou El-Fadl yang mencoba menyoroti kesalahan metodologis dalam memahami teks-teks hukum yang ada di dalam al-Qur'ān dan Sunnah yang dianggap mendiskriminasi bagi kaum perempuan. Banyak fatwa yang dikeluarkan oleh ahli hukum Islam, baik atas nama pribadi maupun lembaga, yang mengandung bias gender dan cenderung menyudutkan kaum perempuan. Salah satunya adalah wanita tidak boleh menjadi pemimpin, bepergian tanpa mahram dan mengendarai mobil. Maka dari itu diperlukan sebuah metodologi pembacaan baru terhadap teks-teks keagamaan, agar hukum Islam itu bersifat elegan, egaliter dan solutif. Disinilah tepat kiranya bahwa hermeneutika negosiatif sebagai solusinya. Akan tetapi diperlukan tiga hal untuk memaksimalkan kerja hermeneutika negosiatif ini, yaitu: kompetensi dan validitasi teks, penetapan makna dan konsep perwakilan. Jika tiga hal ini bisa dilakukan, maka hukum Islam akan terus berkembang dan relevan untuk setiap tempat dan waktu. ${ }^{4}$

Abou El Fadl mendikotomi Umat Islam ke dalam dua kubu besar yakni moderat dan puritan. Dalam bukunya The Great Theft: Wrestling Islam from the Extremists, ${ }^{5}$ Khaled banyak mengulas tentang kedua kubu ini. Baik moderat dan puritan menurutnya mengklaim diri sebagai representasi Islam yang benar dan otentik yang sama-sama ingin tersambung dan bisa menjalani hidupnya di muka bumi dengan bimbingan Tuhan. Dalam tulisan ini yang menjadi fokus pembahasan yaitu: Bagaimana Metode pemikiran Hermeneutika Khaled M. Abou El Fadl terhadap aliran puritanisme dan moderatisme dalam Islam? Sebagai pendukung jalannya penelitian ini peneliti menggunakan metode deskriptif analisis.

Metode heremeneutika Khaled lebih lunak dalam membaca teks-teks keagamaan. Dalam beberapa pandangan, dia sangat

${ }^{3}$ https://www.researchgate.net/publication/323242162. Diakses 13 Maret 2019.

${ }^{4}$ Raisul, "Pemikiran Hukum Islam Khaled Abou El Fadl" dalam Jurnal MAZAHIB Jurnal Pemikiran Hukum Islam Vol. XIV, No. 2 (Desember 2015).

${ }^{5}$ Khaled Abou El Fadl, Selamatkan Islam dari Muslim Puritan, terj. Helmi Mustafa (Jakarta: Serambi, 2007). 
mengapresiasi tradisi fikih dalam Islam yang menjunjung tinggi perbedaan (ikhtiläf), ${ }^{6}$ dan pada sisi lain dia menggunakan teori-teori Barat yang diinternalisasi dengan cukup kritis. Lebih jauh, model pembacaan Khaled ini merupkan respon yang produktif terhadap fatwa-fatwa dari lembaga hukum Islam, khususnya dari golongan Wahabi yang dianggap bersifat otoriter. Oleh karena itu, Khaled menawarkan sebuah perangkat operasional dalam menafsirkan teks atau memaknainya khususnya dalam menghasilkan sebuah hokum.

\section{B. Hermeneutika}

Hermeneutika pada dasarnya adalah suatu metode atau cara untuk menafsirkan simbol yang berupa teks atau sesuatu yang diperlukan sebagai teks untuk dicari arti dan maknanya, metode hermeneutika ini mensyaratkan adanya kemampuan untuk menafsirkan masa lampau yang tidak dialami, kemudian dibawa ke masa sekarang. ${ }^{7}$ Beberapa tahun terakhir ini, kajian-kajian mengenai hermeneutika atau kajian-kajian yang memanfaatkan hermeneutika sebagai pendekatannya semakin populer dan dipakai oleh berbagai ilmuan dari berbagai bidang kajian, termasuk para pengkaji agama Islam. Dalam disipilin kajian hermeneutika, untuk memperoleh makna secara komprehensif, seorang penafsir tidak hanya dituntut kemampuannya dalam memahami makna yang disimbolkan oleh teks, tetapi harus pula memperhatikan konteks dari teks tersebut, baik konteks ketika teks itu dibaca maupun konteks ketika teks itu muncul. diakhir tugasnya, seorang penafsir bertanggung jawab menyampaikan pemahaman yang diperoleh tersebut terhadap orang lain dalam kerangka lintas budaya. ${ }^{8}$

Secara umum, hermeneutika dibagi menjadi dua, yaitu heremeutical theory (hermeneutika teoritis) yang berisi aturan metodologis untuk sampai kepada pemahaman yang diinginkan

${ }^{6}$ Khaled M. Abou Fadl, Atas Nama Tuhan: Dari Fikih Otoriter ke Fikih Otoritatif, terj. R. Cecep Lukman Yasin (Jakarta: PT. Serambi Ilmu Semesta, 2004), h.23.

85.

${ }^{7}$ Sudarto, Metodologi Penelitian Filsafat (Jakarta: Rajawali Pers, 1996), h.

${ }^{8}$ Fahruddin Faiz, "Teks, Konteks, Kontekstualisasi (Hermeneutika Modern dalam Ilmu al-Qur'an Kontemporer)", dalam M. Amin Abdullah, et al., Tafsir Baru Studi Islam dalam Multikultural (Yogyakarta: IAIN Sunan Kalijaga, 2002), h. 40.

IJITP, Vol. 1, No. 1, (2019) 
pengarang dan hermeneutical philosophy (hermeneutika filosofis) yang lebih mencermati dimensi ontologis-fenomenologis pemahaman. ${ }^{9}$ Hermeneutika teoritis memusatkan perhatian kepada bagaimana memperoleh makna yang tepat dari teks atau sesuatu yang dipandang teks, sedangkan makna yang dimaksudkan adalah makna yang dikehendaki oleh pengarang teks. Heremeneutika ini juga disebut hermeneutika romantik, karena memahaminya secara objektif maksud pengarang atau bertujuan untuk 'merekontruksi makna'. Adapun hermeneutika filosofis melangkah lebih jauh dengan menggali asumsi-asumsi epistemologis dari penafsiran ke dalam aspek historisitas, tidak hanya dalam dunia teks, tetapi juga dunia pengarang dan pembacanya. Hermeneutika filosofis tidak hanya bertujuan untuk 'merekontruksi teks', tapi juga bertujuan untuk 'memproduksi makna'. Menyadari bahwa teks dan pengarangnya saling bertautan namun jarang sekali keduanya hadir bersama-sama di hadapan pembaca, maka dalam setiap pemahaman dan penafsiran sebuah teks, faktor subjektivitas pembaca menjadi sangat berperan. Dengan demikian, hermeneutika dapat dikatakan bergerak dalam tiga horizon, yaitu horizon teks (the world of the text), horizon pengarang (the world of author), dan horizon pembaca (the world of reader). ${ }^{10}$

Salah satu bidang kajian agama yang paling dekat dengan hermeneutika adalah kitab suci, karena hermeneutika pada awal perkembangannya sangat membantu dalam penafsiran kitab suci Bibel (Biblical exegesis) di kalangan gereja dan kemudian berkembang menjadi 'filsafat penefsiran'. Selanjutnya, Friedrich Schleiermacher membakukan hermeneutika sebagai suatu metode umum interpretasi yang tidak terbatas pada kitab suci dan sastra. Wilhelm Dilthey menerapkannya sebagai metode sejarah, lalu Hans George Gadamer mengembangkannya menjadi filsafat, dan Paul Ricoeur menjadikannya sebagai 'metode penafsiran', baik dalam bidang filsafat, teologi, maupun ilmu-ilmu sosial dan ilmu-ilmu humaniora. ${ }^{11}$ Meski hermeneutika dapat dipakai sebagai alat untuk menafsirkan berbagai bidang kajian keilmuan, melihat sejarah

${ }^{9}$ Hans George Gadamer, Truth and Methode (New York: The Seabury Press, 1975), h. xvi. 2004), h. 3.

${ }^{0}$ Komaruddin Hidayat, Menafsirkan Kehendak Tuhan (Jakarta: Teraju,

${ }^{11}$ F. Budi Hardiman, Seni Memahami: Hermeneutik dari Schleiermacher sampai Derrida (Yogyakarta: Kanisius, 2015), h. 239. 
kelahiran dan perkembangannya, harus diakui bahwa peran hermeneutika yang paling besar adalah dalam bidang ilmu sejarah dan kritik teks (literary criticism), khususnya kitab suci.

Dalam Islam, jika pendekatan hermeneutika dipertemukan dengan kajian teks Alquran, maka persoalan dan tema yang dihadapi adalah bagaimana teks Alquran hadir di tengah masyarakat, lalu dipahami, ditafsirkan, diterjemahkan, dan didialogkan dalam kerangka realitas historis yang menjadi konteksnya. Dalam kajian Islam sendiri, metode hermeneutika telah diperkenalkan dan diterapkan oleh para pemikir Muslim kontemporer, seperti Mohammad Arkoun, Fazlur Rahman, Nasr Hamid Abu Zayd, Hasan Hanafi, Farid Essack, dan Khaled Abou El-Fadl. Asumsi kuat dari para pendukung hermeneutika, bahwa pemahaman konvensional terhadap sumber dan ajaran Islam sudah tidak relevan lagi untuk konteks sekarang, karenanya perlu diganti dengan metode pemahaman baru, yaitu hermeneutika. Asumsi lainnya, bahwa sebuah teks selain produk si pengarang, juga merupakan produk budaya atau episteme suatu masyarakat. Karenanya, konteks historis dari teks menjadi sesuatu yang sangat signifikan untuk dikaji dalam memahami makna sebuah teks. Lebih jauh lagi, metode penafsiran teks seharusnya tidak hanya memperhatikan hubungan penafsir dan teks, tanpa pernah mengekplisitkan kepentingan audiens terhadap teks.

Sehubungan dengan pendekatan hermeneutika terhadap Alquran, perlu diperhatikan tiga hal yang menjadi asumsi dasar dalam penafsirannya. Pertama, para penafsir itu adalah manusia yang membawa muatan-muatan kemanusiaan masing-masing, sehingga tidaklah mengherankan jika akhirnya ada beragam interpretasi dari setiap generasi Muslim sejak masa Nabi Muhammad SAW. Kedua, penafsir itu tidak dapat lepas dari bahasa, sejarah, dan tradisi. Artinya, satu penafsir tidak bisa sepenuhnya mandiri berdasarkan teks, tetapi pasti terkait dengan muatan historisnya, baik muatan historis saat teks muncul maupun saat teks ditafsirkan. Ketiga, tidak ada teks yang menjadi wilayah bagi dirinya sendiri. Dalam hubungannya dengan 
pewahyuan Alquran, maka ia harus dipahami dalam bentuk kondisi masyarakt tertentu di mana wahyu itu turun. ${ }^{12}$

Pendekatan hermeneutika umumya membahas pola hubungan segitiga (triadic) antara pengarang (pembuat teks; author), teks (text), dan pembaca (penafsir teks; reader). Inti analisis hermeneutika terletak pada peran pengarang, teks, dan pembaca dalam menentukan makna. Hermeneutika hendak menjembatani jarak antara pengarang dan pembaca, antara keduanya dimediasi oleh teks. Dalam sejarah keilmuan Islam, istilah hermeneutika sendiri memang tidak ditemukan. Meski demikian, praktik hermeneutika sebenarnya telah dilakukan oleh umat Islam sejak lama sekali, yaitu sejak Alquran diwahyukan kepada Nabi Muhammad Saw. Terminologi khusus yang digunakan dalam pengertian kegiatan interpretasi dalam wacana keilmuan Islam adalah tafsir, kegiatan yang digunakan secara teknis dalam pengertian exegesis di kalangan umat Islam sejak abad pertama Hijriyah hingga sekarang. Jika dilihat dari arti terminologinya, kata heremeneutika sebenarnya setara tidak saja dengan kata tafsir, tetapi juga dengan kata ta'wil, sharh, dan bayan. Karenanya, Amin Abdullah menyebut hermeneutika sebagai al-ta'wil al-ilmi atau fiqh al-tafsir wa al-ta' wil. ${ }^{13}$

Sebagaimana dinyatakan oleh Abou El-Fadl, bahwa para sarjana Islam telah melahirkan sebuah tradisi penafsiran Alquran yang luar biasa, dikenal dengan ilm al-tafsir. Ilmu ini cenderung berkonsentrasi pada upaya pengembangan berbagai kaidah untuk memecahkan makna teks berdasarkan waktu dan tempat turunnya. Dalam upaya melakukan penafsiran, para sarjana pramodern telah mengkaji maksud dan makna wahyu berdasarkan teks. Konteks sebuah teks diteliti terutama melalui ilmu tentang sebab-sebab pewahyuaan (ilm asbab al-nuzul), tapi penelitian kontekstual ini pada prinsipnya berkonsentrasi pada upaya memahami maksud awal Pengarang. Selain ilm al-tafsir, ada juga proses interpretasi dinamis yang mengitari teks Alquran. Interpretasi yang dimaksudkan di sini adalah proses menggali konteks kekinian dari makna asal sebuah teks.

12 Fahruddin Faiz, Herneneutika al-Qur'an: Tema-tema Kontroversial (Yogyakartka: eLSAQ, 2005), h. 16-17.

${ }^{13}$ M. Amin Abdullah, "al-ta'wil al-ilmi ke Arah Perubahan Paradigma Penafsiran Kitab Suci,” dalam Abdullah, et al., Tafsir Baru Studi Islam dalam Era Multikultural, h. 1-37. 
Sementara, ilm al-tafsir berkonsentrasi pada upaya memahami makna pengarang, interpretasi membahas dampak dan kedudukan penting dari makna asal sebuah teks. Proses interpretasi ini tidak berkonsentrasi pada maksud asal teks untuk melayani teks, tapi untuk merespon realitas sosial politik dengan menggunakan teks. Hubungan antara ilmu tafsir dan interpretasi inilah yang sebenarnya menjadi fokus kajian dalam disiplin hermeneutika pada abad modern ini, termasuk hermeneutika yang digagas Abou El-Fadl dalam wilayah hukum Islam. ${ }^{14}$

\section{Pemikiran Islam Abou El Fadl}

\section{Puritan Perspektif Abou El Fadl}

Abou El Fadl menggunakan puritan dengan maksud yang sama dengan istilah fundamentalis, militan, radikal, fanatik, jihadis dan juga ekstrimis. Hanya saja, Abou El Fadl lebih suka menggunakan istilah puritan, karena menurutnnya, kelompok ini mengandung ciri cenderung tidak toleran, bercorak reduksionisme fanatik, literalisme, dan memandang realitas pluralis sebagai bentuk kontaminasi atas kebenaran sejati. ${ }^{15}$

Menurut Khaled, ciri khas pemikiran mereka itu menganut absolutisme dan menuntut adanya kejelasan dalam menafsir teks, bukan watak fanatik, radikal atau ekstremis mereka. ${ }^{16}$ Gerakan yang disebut puritan ini, menurut Khaled, bisa dilacak konteks historisnya pada tahun 1970an, yang dalam tahun itu, umat Islam menyaksikan kebangkitan Islam yang mengambil bentuk gerakan puritan berorientasi-kekuasaan yang menyerukan kembali kepada identitas Islam otentik melalui penerapan syariat Islam. Seruan-seruan ini merupakan tema-tema umum yang terjadi setiap saat pada era kolonial.

Islam puritan memperlakukan Islam secara kaku dan tidak dinamis. Mereka sangat membesar-besarkan peran teks dan memperkecil peran aktif manusia dalam menafsirkan teks keagamaan. Dalam hal ini orientasi Islam puritan mendasarkan diri dibalik kepastian makna teks, sehingga implementasi perintah Tuhan, yang

\footnotetext{
${ }^{14}$ Abou El Fadl, Speaking in God's Name, h. 118.

${ }^{15}$ Khaled Abou El Fadl, Selamatkan Islam dari Muslim Puritan, h. 29-32.

${ }^{16}$ Ibid., h. 30-31.
} 
seutuhnya dan secara menyeluruh seakan sudah termaktub di dalam teks, bukan pada nuansa kontekstualisasi.

Puritanisme melawan era modern dengan berlindung pada literalisme yang ketat, yang dalam payung itu teks menjadi satusatunya sumber legitimasi. Ia mencoba kembali kepada masa keemasan Islam, kepada suatu tatanan negara adil dan sempurna yang diciptakan oleh Muhammad. Menurut kaum puritan, kita wajib kembali kepada Islam yang lurus dan sederhana, yang itu bisa diperoleh hanya dengan kembali kepada penerapan literal terhadap perintah-perintah dan sunnah $\mathrm{Nabi}$, serta pelaksanaan yang ketat terhadap praktik-praktik ritual. Orientasi puritan juga menganggap bentuk pemikiran moral yang tidak sepenuhnya bergantung pada teks sebagai bentuk pemberhalaan diri, dan menganggap wilayah-wilayah pengetahuan humanistik, seperti teori sosial, filsafat, atau pemikiran spekulatif lainnya, sebagai "ilmu sesat". ${ }^{17}$

Sementara itu, dalam menyikapi dialektika tradisi dengan modernitas, Islam puritan dengan tegas menolak modernitas. Islam puritan secara terbuka mengidolakan generasi awal atau zaman keemasan Islam, yaitu era Nabi di Madinah dan masa al-Khulafâ ' al Râshidûn. Epistemologi yang dibangun oleh Islam puritan adalah bahwa Islam telah mencapai aktualisasi potensi penuh pada satu periode sejarah tertentu, yakni generasi awal. Oleh karenanya di mata Islam puritan, untuk benar-benar modern umat Islam harus merebut kembali masa silam itu dengan cara meniru dan mereplikasikan di dalam dunia modern. Dengan kata lain, kompas perkembangan Islam puritan diarahkan pada masa silam. Akan tetapi keyakinan semacam ini, dalam pandangan Abou Fadl justru membuat Islam puritan mendera keterasingan di dunia modern dan ini sekaligus hanya menghasilkan sikap despotisme ganas. Rasa keterasingan ini memunculkan sikap anti Barat. ${ }^{18}$

Dalam banyak hal, gerakan puritan mereproduksi kondisikondisi mental yang diadopsi oleh gerakan apologetik. Ia menghindari pendekatan-pendekatan analitis atau historis dalam memahami Islam, dan mengklaim bahwa semua tantangan yang dihadirkan oleh modernitas bisa dipecahkan dengan kembali kepada Alquran dan Sunnah Nabi. Dalam paradigma Islam puritan, Islam itu

\footnotetext{
${ }^{17}$ Khaled Abou El Fadl, Selamatkan Islam dari Muslim Puritan, h. 121.

${ }^{18}$ Ibid., h. 197-209.
} 
sudah sempurna, kesempurnaan itu berarti bahwa Islam tidak merekonsiliasikan dirinya atau membuktikan dirinya sesuai dengan sistem pemikiran lainnya. Islam merupakan sebuah sistem keyakinan dan hukum yang sudah lengkap dalam dirinya yang mencoba membentuk dunia dalam gambarannya, ketimbang mengakomodasi pengalaman manusia. ${ }^{19}$

Sikap ini muncul dari perdebatan tentang hakimiyyah (kedaulatan) dalam sejarah Islam. Menurut puritan, kedaulatan Islam adalah milik Tuhan itu sendiri, yang merupakan satu-satunya Pencipta hukum. Oleh karena itu, posisi normatif apa pun yang diambil dari akal manusia atau pengalaman-pengalaman socialhistoris pada dasarnya tidak valid. Satu-satunya posisi normatif yang dibolehkan adalah yang diserap dari pemahaman terhadap perintahperintah Tuhan, seperti yang ditemukan dalam teks-teks suci. Oleh karenanya, tidak mengejutkan jika orientasi puritan menganggap semua pendekatan moral yang berlindung pada intuisi, akal, kewajiban-kewajiban kontraktual, atau konsensus sosial dan politik, sebagai aneh dan tidak valid. Semua norma moral dan hukum mesti diambil dari satu-satunya sumber, yaitu keinginan Tuhan.

Konsekuensi dari posisi, sikap, pendekatan dan pemahaman literal dari gerakan puritan ini dalam sebagian hal adalah sebagai berikut: ${ }^{20}$

a. Anti demokrasi dan hak asasi manusia, yang dianggap sebagai produk Barat.

b. Anti pluralisme agama, bahkan gerakan puritan menuntut agar umat Islam menampakkan kebencian dan permusuhannya kepada orang-orang kafir (musyrik) dengan menegaskan bahwa seorang Muslim seharusnya tidak boleh mengadopsi kebiasaan-kebiasaan orang kafir dan tidak bersahabat dengan mereka. Ini harus diperlihatkan secara terangterangan dan tidak ambigu.

c. Anti kesetaraan gender dan feminisme, yang dianggap sebagai doktrin Barat untuk menghancurkan identitas keislaman yang otentik.
${ }^{19}$ Ibid., h. 309.
${ }^{20}$ Khaled Abou El Fadl, Selamatkan Islam dari Muslim Puritan, h. 217329. 
d. Pembenaran kekerasan dan teror atas nama agama, karena ini, menurut mereka, merupakan bagian dari jihad defensif yang menegaskan bahwa umat Islam telah dizalimi.

2. Moderat Perspektif Aboe Fadl

Moderat dalam perspektif Khaled Abou El Fadl senada dengan istilah modernis, progresif, dan reformis. Namun demikian istilah moderat ia pilih karena lebih tepat untuk menggambarkan kelompok yang ia hadapkan dengan kelompok puritan. Menurutnya istilah modernis mengisyaratkan satu kelompok yang berusaha mengatasi tantangan modernitas yang problem kekinian. Bukan hanya itu, Khaled juga mengklaim bahwa sikap moderasi menggambarkan pendirian keagamaan mayoritas umat Islam saat ini.

Khaled juga menghindari istilah progresif sebagai ganti dari moderat karena alasan isu liberalisme dan hubungannya dengan reformasi dan kemajuan. Menurutnya, progresivitas dan reformisme adalah sikap kaum elit intelektual dan tidak mewakili mayoritas Umat Islam. Abou el-Fadl menggaris-bawahi bahwa akar moderat telah ditanamkan oleh Rasulullah SAW manakala beliau dihadapkan pada dua pilihan ekstrem, akhirnya Nabi SAW selalu memilih jalan tengah. $^{21}$

Muslim moderat merupakan orang-orang yang yakin pada Islam sebagai keyakinan yang benar, yang mengamalkan dan mengimani lima rukun Islam, menerima warisan tradisi Islam, namun sekaligus memodifikasi aspek-aspek tertentu darinya demi mewujudkan tujuan-tujuan moral utama dari keyakinan itu di era modern. $^{22}$ Mereka meyakini Islam, menghormati kewajibankewajiban kepada Tuhan, dan meyakini bahwa Islam sangat pas untuk setiap saat dan zaman. Mereka tidak memperlakukan agama mereka laksana monumen yang beku, tetapi memperlakukannya dalam kerangka iman yang dinamis dan aktif. Konsekuensinya, Muslim moderat menghargai pencapaian-pencapaian sesama Muslim di masa silam, namun mereka hidup di zaman sekarang. ${ }^{23}$

Untuk memahami hukum abadi Tuhan yang termodifikasi dalam wujud al-Qur'ân, Islam moderat memandang bahwa al-Qur'ân

\footnotetext{
${ }^{21}$ Abou El Fadl, Selamatkan Islam dari Musllim Puritan, h. 27.

${ }^{22}$ Khaled Abou El Fadl, Selamatkan Islam dari Muslim Puritan, h. 130.

${ }^{23}$ Ibid., h. 133.
} 
benar-benar telah menyampaikan putusan secara spesifik terhadap persoalan tertentu dan putusan spesifik yang seperti itu harus dipahami dalam kaitannya dengan konteks. Putusan sepesifik di dalam al-Qur'ân yang di maksud adalah muncul dalam merespons persoalan-persoalan tertentu yang dihadapi umat Islam pada zaman Nabi. Maksud dari putusan spesifik dan khusus yang dinyatakan di dalam al-Qur'ân bukanlah tujuan itu sendiri, melainkan putusan yang diwahyukan pada waktu itu adalah untuk mencapai tujuan moral dari al-Qur'ân seperti keadilan, keseimbangan, kesetaraan, kasih sayang, kebajikan dan seterusnya. Dengan kata lain, tujuan moral dan etis yang disampaikan oleh alQur'ân memainkan peran sentral dan penting dalam proses analisis hukum. ${ }^{24}$

Sedangkan terhadap Hadits, Islam moderat menerapkan prinsip-prinsip sistematis dalam bentuk dalam bentuk kritik sejarah terhadap Hadits-Hadits yang dinisbatkan pada Nabi. Karena suatu kenyataan bahwa Hadits terkodifikasi dan terpelihara satu abad sepeninggal Nabi, adalah sesuatu yang tidak dapat dihindari akan cerminan lingkungan historis, perselisihan sektarian, dan konflik politik. Menghadapi situasi yang demikian, Islam moderat menggunakan metode analisis kritis dengan meneliti kondisi-kondisi lingkungan yang melingkupi. Tujuannya untuk menyakinkan bahwa setiap riwayat yang ada dapat dipahami dengan baik secara historis maupun rasional. ${ }^{25}$

Terkait dengan motif, pada dasarnya semua proyek yang dilakukan Khaled dalam mengkritik bangunan teoritis dan praksis dari gerakan-gerakan puritan bermuara pada keinginan Khaled untuk menciptakan suatu masyarakat madani yang mencakup individuindividu Muslim yang moderat seperti yang digambarkan di atas, yang toleran, anti kekerasan, pluralis, demokratis, penuh kasih terhadap makhluk Tuhan, dan lebih menghargai hak asasi manusia. Kepentingannya bukan bersifat ideologis, namun praktis, yaitu Islam yang moderat, cerdas, kreatif, penuh semangat juang yang merupakan cerminan dari rahmat bagi seluruh alam. Karena jika individuindividu seperti ini terbentuk, maka wajah Islam yang pada dasarnya indah, akan tampak bersinar kembali sebagaimana itu pernah terjadi pada masa-masa keemasan Islam yang pada periode itu wacana

\footnotetext{
${ }^{24}$ Ibid., h. 189-190.

${ }^{25}$ Ibid., h. 187-198.
}

IJITP, Vol. 1, No. 1, (2019) 
intelektual berjalan begitu bebas dan dinamis. Dan orang-orang moderat inilah yang diharapkan Khaled menjadi counter hegemony terhadap tafsiran-tafsiran dan gerakan-gerakan puritan yang pengaruhnya begitu kontra-produktif terhadap Islam dan masyarakat Muslim.

\section{Hermeneutika Abou El Fadl}

Hermeneutika Abou El-Fadl dapat disebut 'hermeneutika negosiatif'. Menurutnya, makna harus merupakan hasil interaksi antara pengarang, teks, dan pembaca, di mana harus ada keseimbangan (balancing) dan proses negosiasi antara ketiga pihak, serta salah satu pihak tidak boleh mendominasi dalam proses penetapan makna. ${ }^{26}$ Dengan demikian, penetapan makna teks selalu melibatkan proses yang kompleks, interaktif, dinamis, dan dialektis antara ketiga unsur dalam lingkungan hermeneutis, yaitu pengarang, teks, dan pembaca. Menurut penulis, dalam konteks kajian keislaman secara umum dan hukum Islam secara khusus, argumen Abou El-Fadl tersebut menunjukkan pentingnya pembagian peran yang sama besar antara pengarang, teks, dan pembaca -yang dalam hal ini diperankan oleh para ahli hukum (wakil khusus)- dalam menemukan hukum Tuhan. Melalui mereka makna teks-teks hukum diperdebatkan, dinegosiasikan, dan terus mengalami perubahan. Tidak boleh ada kekuasaan yang terlebih pada salah satu pihak dalam penetapan hukum. Sebaliknya, masing-masing pihak harus saling menegosiasikan makna teks-teks hukum, untuk menghindari kemungkinan terjadinya ketegangan antara Tuhan, teks, dan para ahli hukum. Selain itu, hermeneutika Abou El-Fadl termasuk dalam kategori hermeneutika filosofis, karena proses hermeneutis dipahami olehnya tidak sekedar bertujuan untuk 'merekonstruksi makna', tetapi juga bertujuan untuk 'mereproduksi makna'.

Abou Fadl dalam karya-karyanya sebenarnya tidak secara eksplisit mengkonsep hermeneutik layaknya filusuf bahasa dan lebih banyak mempraktekkannya. Hermeneutik yang ada atau dinisbatkan padanya lebih pada konseptualisasi dan konstruksi yang ada pada pemikirannya, terutama dalam bukunya Speaking in God's Name: Islamic Law, Authority and Woman, Abou Fadl berkata:

\footnotetext{
${ }^{26}$ Ibid., h. 90
} 
"I mean the process of exploring the contemporaneous significance of the original meaning. While exegesis focused on deciphering the meaning of the Author, interpretation dealt with the implications and significance of the original meaning." 27

Namun demikian, menurut analisis Khaled, perangkat hermeneutika adalah solusi dalam menghadapi fenomena otoritarianisme dalam pemikiran Islam, khususnya dalam penelitiannya tentang diskursus hukum Islam. Dan ini merupakan prosedur metodologis terkait dengan relasi antara ketiga unsur pengarang, teks, dan pembaca. Dalam pembacaan Prof. Amin Abdullah pendekatan tersebut digunakan Khaled untuk memposisikan bagaimana sesungguhnya hubungan antara teks (text) atau nash, penulis atau pengarang (author), dan pembaca (reader). ${ }^{28}$ Untuk itu Khaled membuat konsepsi baru terkait dengan teks (al-Qur'an dan sunnah), pengarang, dan pembaca.

1. Al-Qur'an dan Hadits adalah teks terbuka

Menurut Khaled, al-Qur'an dan Sunnah walaupun berbeda dalam tingkat hirarkinya, haruslah diperlakukan sama. Dalam hal ini, baginya- meminjam istilah Umberto Eco- teks adalah karya yang terus berubah. Dalam artian keduanya terbuka untuk berbagai interpretasi. Asumsi yang demikian akan menjadikan teks berbicara dengan suara yang diperbaharui oleh masing-masing generasi pembaca (reader) karena maknanya tidak permanen dan berkembang secara aktif. Jadi, sebuah teks akan tetap relevan dan menduduki posisi sentral karena keterbukaannya. Para pembaca akan selalu kembali merujuk kepada teks karena teks dapat menghasilkan pemhaman dan interpretasi baru. ${ }^{29}$

Disini dapat difahami bahwa al-Qur'an dan sunnah menurut Khaled adalah bersifat bebas, terbuka, dan otonom. Sehingga segala bentuk penafsiran dan pemahaman akan terus aktif, dinamis dan progresif. Dalam analisis Khaled, hal inilah yang dibenarkan secara moral.

${ }^{27}$ Khaled M. Abou El Fadl, Speaking in God's Name: Islamic Law, Authority and Woman, h. 246.

28 Amin Abdullah, "Pendekatan Hermeneutik dalam Studi Fatwa-fatwa Keagamaan", h. viii.

${ }^{29}$ Khaled M. Abou Fadl, Atas Nama Tuhan: Dari Fikih Otoriter ke Fikih Otoritatif, h. 212. 
Menurutnya, jika teks al-Qur'an dan sunnah diinterpretasi menjadi sebuah makna yang stabil, tetap dan tidak berubah, maka konsekwensinya adalah teks menjadi tertutup dan menyegel maknanya dengan interpretasi pembaca. Secara moral hal ini tidak dibenarkan karena merupakan bentuk kesombongan. Karena seorang pembaca mengklaim memiliki suatu pengetahuan yang identik dengan pengetahuan Tuhan. Dengan demikian seakan-akan ia berbicara bahwa interpretasinya identik dengan makna teks yang sebenarnya. Bagi Khaled ini akan berakibat kepada hilangnya otonomi teks, dan secara teologis ini bermasalah karena bersebrangan dengan kemutlakan pengetahuan Tuhan. Al-Qur'an secara tegas menyatakan kemutlakan Tuhan dan pengetahuan-Nya yang tidak bisa disejajarkan dengan pengetahuan siapapun. ${ }^{30}$

2. Pembaca dan Lima Prasyaratnya

Walaupun Khaled menganggap al-Qur'an sebagai teks yang bebas, terbuka dan otonom, namun demikian Khaled merasa perlu membatasi otoritarianisme pembaca dengan lima syarat. Prasyarat ini harus dipenuhi atau dilaksanakan. Karena apabila tidak mencukupi, maka pembaca khususnya para wakil khusus atau mujtahid telah melakukan tindakan di luar kewenangan hukum yang dimilikinya (ultra vires). Kelima prasyarat yang menjadi landasan pelimpahan otoritas tersebut adalah sebagai berikut: ${ }^{31}$

Pertama, adalah kejujuran (honesty). Wakil Tuhan harus memiliki kejujuran dan dapat dipercaya untuk menerjemahkan perintah Tuhan. Ia harus menghindari keberpuraan memahami apa yang sebenarnya tidak diketahui, dan bersikap jujur tentang sejauh mana ilmu dan kemampuannya dalam memahami perintah Tuhan. Kedua, ketekunan (diligency) dalam mengerahkan segenap kemampuan rasionalitasnya untuk menemukan dan memahami kehendak Tuhan. Ketiga, komprehensifitas (comprehensiveness) dalam menyelidiki kehendak Tuhan. Seorang penafsir harus melakukan penyelidikan perintah-perintah Tuhan secara menyeluruh dengan mempertimbangkan hal-hal yang relevan, dan tidak melepas tanggungjawabnya untuk menyelidiki atau menemukan alur pembuktian tertentu. Keempat, penggunaan rasionalitas (rasionality) dalam penafsiran dan analisis terhadap perintah-perintah Tuhan.

\footnotetext{
${ }^{30}$ Ibid., h. 212-213.

${ }^{31}$ Ibid., h. 98-103.
} 
Penafsiran teks harus dilakukan secara rasional, atau setidaknya dengan ukuran yang benar menurut paradigma umum. Artinya, pembaca tidak boleh berlebihan dalam menafsirkan teks sehingga melahirkan kesimpulan bahwa makna teks tersebut benar-benar seperti yang diinginkan pembaca, dan bukan menampilkan maksud yang memang dikehendaki teks. Kelima, pengendalian diri (selfrestaint) atau kerendahan hati dalam menjelaskan kehendak Tuhan. Pengendalian ini lebih merupakan kewaspadaan tertentu untuk menghindari penyimpangan, atau kemungkinan penyimpangan atas peran pengarang (Tuhan).

Teks harus dipahami dengan melihat kepada konteks kesejarahannya agar bisa diketahui pesan apa yang sebenarnya ingin disampaikan Tuhan dalam teks itu. Dengan demikian, mengetahui sebab yang memunculkan turunnya sebuah teks itu menjadi penting, seperti dalam kasus ayat hijab, misalnya. Begitu pula, ketika teks itu dalam bentuk hadis Nabi, maka perlu dilihat pula konteks kesejarahan hadis itu, agar bisa dipahami apa pesan yang ingin disampaikannya, seperti, siapa yang mengatakan hadis itu, dalam konteks apa, siapa yang menjadi sasaran target hadis itu, dan begitu seterusnya. Jika yang mengucapkan itu Nabi, maka dalam konteks masyarakat seperti apa Nabi menyatakannya. Jika hadis itu kemudian ditransmisikan oleh sahabat atau tabi,,in, maka siapa yang meriwayatkannya, dalam konteks apa, apa ideologi dan kepentingan dan konteks si perawi, dan seterusnya. Begitu pula, perlu dianalisis pemahaman komunitas penafsir terhadap peran Nabi dalam proses tersebut. ${ }^{32}$ Oleh karena itu, menyikapi sebuah teks dengan rasional-kritis, tanpa membabi buta, dan dengan pendekatan kesejarahan, lebih akan mengantarkan kepada pesan yang diinginkan teks itu.

\section{E. Hermeneutika Deliberatif: Kritik atas Hermeneutika Abou El Fadl}

Konsepsi Abou El Fadl mengenai teks Alquran, Sunnah dan prasyarat pembaca adalah sebuah konsepsi untuk mewujudkan negosiasi makna antara pembaca dan teks. Dalam proses negosiasi itu, Khaled menekankan pentingnya latar belakang sosial historis

${ }^{32}$ Ibid., h. 163-164. 
Alquran. ${ }^{33}$ Ia menyatakan wahyu selalu dimediasikan oleh kondisikondisi historis yang berlaku. Sehingga, sangat penting untuk menganalisis situasi historis yang menegosiasikan norma-norma etis Alquran tertentu. Banyak institusi yang diacu dalam Alquran menurut Khaled hanya dapat dipahami jika pembacanya menyadari praktikpraktik historis yang melingkupi pewahyuan teks tersebut. Namun dengan memisahkan Alquran baik dari sejarah maupun dari konteks moralnya, maka para penafsir, menurutnya, hanya berujung pada pengubahan teks menjadi daftar panjang perintah hukum yang secara moral tidak jelas.

Prinsip negosiasi di atas, sekaligus mengimplikasikan bahwa dalam perspektif hermeneutik, kebenaran pengetahuan tidak pernah bersifat final (the fallibility of knowledge). Karena itulah hermeneutika pada dasarnya tidak menafikan eksistensi dari otoritas, baik itu otoritas teks, pengarang dan pembaca (reader/ audience), akan tetapi melawan segala bentuk dominasi dan monopoli dalam penetapan makna teks. Hermeneutika dalam hal ini berada dalam wilayah publik yang hendak mendialogkan berbagai asumsi kebenaran yang datang dari para pembaca teks. Teks sebagai panduan moral tentu bersifat otoritatif, akan tetapi tatkala direproduksi oleh pembacanya bisa saja ia menjadi otoriter. Inilah yang disebut dengan intervensi pembaca teks (human intervention) dalam penetapan makna teks berdasar interest, atau kepentingan pembacanya.

Negoisasi ini dalam pandangan Abou El Fadl merupakan bentuk interpretasi otoritatif dengan berdasarkan rasio bukan interpretasi otoriter yang taklid buta, meminjam definisi Joseph Vining. Dimana akan tercipta sebuah gerak interpretasi yang otoritatif, dan terwujud sebuah relasi yang proporsional dan proses negoisasi antara teks, pengarang dan pembaca. Maka, hukum Islam yang dihasilkan tidaklah otoriter dan tidak sewenang-wenang.

konsepsi pembaca terhadap Alquran dan Sunnah sebagai teks yang terbuka, bebas dan otonom adalah upaya untuk menciptakan gerak interpretasi yang dinamis, sehingga tidak ada makna yang bersifat final atau dianggap final. Dan kelima prasyarat yaitu: kejujuran, kesungguhan, kemenyeluruhan, rasionalitas, dan pengendalian diri- harus dimiliki oleh seorang pembaca, dalam artian

${ }^{33}$ Khaled M. Abou El Fadl, Atas Nama Tuhan, terj. R. Cecep Lukman Yasin (Jakarta: Serambi, 2004), h. 194. 
pembaca teks dalam menghasilkan makna haruslah punya otoritas. Adanya teks yang otonom, dan pembaca yang otoritatif akan menghasilkan relasi dan proses negoisasi yang proporsional sehinga tidak ada lagi pembacaan yang sewenang-wenang dan bertendensi menindas.

Keseluruhan metodologi yang digunakan oleh Abou El-Fadl dimaksudkan untuk mengidentifikasi apa yang disebutnya sebagai kecenderungan otoriter, yang telah mengibiri dan menampilkan tradisi pemikiran Islam secara tidak benar, serta mereduksinya menjadi sebuah proses yang hanya mementingkan hasil. Kecenderungan otoriter tersebut seperti terlihat dalam fatwa-fatwa keagamaan Islam yang merendahkan atau bahkan menindas perempuan, yang sangat problematis lagi mayoritas Muslim di berbagai belahan dunia dan lebih-lebih bagi minoritas Muslim yang tinggal di Barat. Dalam hal ini dapat diberikan penilaian terhadap Abou El-Fadl, yaitu adanya muatan kepentingan dalam membangun teori hermeneutikanya seperti dikemukakan di atas tadi. Kepentingan utama Abou El-Fadl adalah mengokohkan tradisi hukum yang antiotoritarianisme dalam pembentukan hukum Islam. Kepentingan lainnya adalah pembelaan terhadap Muslim minoritas di Barat dan mayoritas Muslim lainnya di berbagai belahan dunia yang sedang dilanda krisis otoritas tekstual. Inilah yang oleh Jurgen Habermas, ${ }^{34}$ seorang tokoh hermeneutika kritis, disebut pertautan antara ilmu pengetahuan (knowledge) dan kepentingan manusia (human interest).

Ilmu pengetahuan tidak akan pernah benar-benar bebas nilai, tetapi semua ilmu pengetahuan dan pembentukan teori selalu dibarengi oleh apa yang disebutnya dengan interest-kognitif tertentu, yaitu suatu orientasi dasar yang mempengaruhi jenis pengetahuan dan objek pengetahuan tertentu. Menurut Habermas, ada tiga interest (kepentingan) yang memang telah tertanam kuat di dalam dasar-dasar antropologi manusia yang kemudian memiliki pengaruh besar dalam kegiatan keilmuan. Pertama, kepentingan bersifat teknis yang kemudian melahirkan ilmu-ilmu alam. Kedua, kepentingan bersifat praktis, yang kemudian melahirkan ilmu-ilmu sosial. Ketiga, kepentingan bersifat emansipatoris, yang kemudian melahirkan ilmu-

${ }^{34}$ F. Budi Hardiman, Kritik Ideologi: Menyingkap Pertautan Pengetahuan dan Kepentingan Bersama Jurgen Habermas (Yogyakarta: Kanisius, 2009), h. 211 dan Frans Magnis Suseno, Pijar-pijar Filsafat (Yogyakarta: Kanisius, 2005), h. 157.

IJITP, Vol. 1, No. 1, (2019) 
ilmu kritis atau kritik ideologi. Perhatian Habermas kemudian diarahkan pada ilmu-ilmu kritis. Dengan memberikan posisi pada interest (kepentingan) sebagai bagian tidak terpisahkan dalam proses keilmuan ini, Habermas dikenal sebagai tokoh hermeneutika yang berpengaruh dewasa ini.

Dalam hermeneutika Abou El-Fadl, yang tampak menonjol adalah interest (kepentingan) bersifat praktis dari Abou El-Fadl untuk memisahkan penafsiran yang otoritatif dan yang otoriter. Meskipin Abou El-Fadl telah mendialogkan tradisi hukum Islam dengan komunitas-komunitas interpretasi dan komunitas-komunitas makna yang relevan, ia belum sampai menjalin dialog dan melakukan tindakan 'diskursus' dengan komunitas lain yang menjadi sasaran kritiknya (kelompok puritan) dalam rangka menghasilkan pengetahuan bersama yang disebut oleh Habermas sebagai 'konsensus'. Abou El-Fadl mestinya melakukan kesepakatan dengan kelompok puritan tadi, tentang siapa ahli hukum yang dipandanng otoritatif dan bagaimana penafsiran otortatif dilakukan dalam rangka menemukan hukum Tuhan. Malahan yang terjadi adalah sebaliknya, bahwa Abou El-Fadl menjadi pihak yang berhadapan vis a vis dengan kelompok puritan sebagai pihak yang lainnya dalam perdebatan yang sedang berlangsung.

Selain itu, kritik Abou El-Fadl terhadap kelompok puritan tadi mengandung sebuah dilema, karena tolak ukur kritiknya sama dengan tolak ukur objek yang sedang dikritiknya, yaitu ideologi. Dengan cara lain, kritik Abou El-Fadl tadi telah menjelma atau merupakan manifestasi lain dari sebuah ideologi. Abou El-Fadl tampak ingin menguasai objek yang dikritiknya secara monologal untuk memaksakan visi-visi dan keyakinan-keyakinannya. Dengan kata lain, penggunaan bahasa sebagai metode hermeneutis masih terjebak pada objektivisme ilmu-ilmu alam atau belum mampu lepas dari ideologi positivistisme yang semestinya dikritisi.

Dengan demikian, hermeneutika hukum Islam yang digagas Abou El-Fadl, atau hermeneutika negosiatif, masih berkutat pada gugusan ilmu empiris-analitis dan ilmu historis-hermeneutis. Hermeneutika Abou El-Fadl belum memasuki wilayah ilmu kritis yang bersifat emansipatoris, dengan membangun 'komunikasi' dan melakukan 'diskursus praktis' dengan komunitas interpretasi lain dalam rangka menghasilkan pengetahuan Bersama yang disebut 
'konsensus'. Karena itu, hermeneutika negosiatif harus dikembangkan lebih lanjut agar semakin jelas dan nyata kontribusinya bagi masyarakat Muslim modern. Dalam kerangka ini, 'hermeneutika deliberatif' merupakan sebuah gagasan bagi terwujudnya diskursus yang inklusif, egaliter, dan bebas dominasi dalam mewujudkan consensus tadi. Kata 'deliberatif' berasal dari kata Latin deliberation, atau dalam bahasa Inggris deliberation, yang berarti konsultasi, menimbang-nimbang, musyawarah, atau pengambilan keputusan secara bersama. Karena inti gagasannya adalah diskursus praktis untuk mencapai saling pengertian antarkomunitas interpretasi, hermeneutika deliberatif dapat pula disebut 'hermeneutika diskursif' ${ }^{35}$

Dalam teori diskursus, Habermas membedakan antara 'diskursus teoritis' dan 'diskursus praktis'. Diskursus teoritis mempermasalahkan klaim kebenaran (truth claim) pernyataanpernyataan teoritis-empiris dan didominasi oleh paradigma filsafat subjek. Filsafat subjek mengandaikan otonomi subjek secara sendirian dapat memutuskan tindakan yang seharusnya dilakukan. Subjek otonom ini mengambil keputusannya secara monologal, tidak membuka dialog dengan subjek-subjek lainnya. Hasil dari keputusan yang diperoleh secara monologal ini lalu diklaim sebagai hakiki, serta apa saja yang hakiki adalah total, sehingga kebenaran dari pengetahuan yang diperoleh oleh subjek yang monologal ini dianggap legitim untuk semua subjek rasional lainnya tanpa dialog.

Menurut Habermas, paradigma subjek tidak tepat lagi dipertahankan dalam masyarakat modern yang plural dalam cara hidup ataupun orientasi nilai mereka. Ia kemudian menawarkan paradigma baru, yaitu paradigma teori komunikasi. Paradigma baru ini memahami pengetahuan adalah sebagai hasil consensus dengan subjek-subjek lain, dan diperoleh melalui prosedur atau proses yang diakui seacra intersubjektif, bukan oleh seorang subjek secara monogal. Tindakan komunilatif adalah tindakan yang mengarahkan diri pada konsensus, kesepakatan, atau saling mengerti satu sama lain. Konsesnsus semacam ini hanya dapat dicapai melalui diskursus praktis yang tidak lain adalah prosedur komunikasi, yaitu proses

${ }^{35}$ F. Budi Hardiman, Demokrasi Deliberatif: Menimbang Negara Hukum dan Ruang Publik dalam Teori Diskursus Jurgen Habermas (Yogyakarta: Kanisius, 2009). 
saling komunikasi secara rasional untuk mencapai pengetahuan bersama yang diterima secara intersubjektif. Dalam diskursus praktis, masyarakat mempersoalkan klaim ketetapan (rightness) dari normanorma yang mengatur tindakan mereka. ${ }^{36}$

Pada dasarnya ciri-ciri formal dari diskursus praktis merupakan prosedur komunikasi. Pada peserta diskursus praktis mencoba memecahkan norma-norma yang problematis secara kooperatif agar mencapai konsensus yang secara intersubjektif sesuai dengan kehendak semua peserta. Tujuan diskursus praktis adalah pemahaman timbal-balik atas norma-norma tindakan yang dipatuhi bersama. Hanya konsensus yang dapat diterima oleh semua peserta secara intersubjektif dan tanpa paksaan yang dianggap rasional. Bagi Habermas, hal ini merupakan prasyarat ideal yang tidak dapat ditawar-tawar lagi, namun prasayarat tersebut tidak muncul begitu saja. Sebuah konsensus yang legitim yang seharusnya dipatuhi oleh semua orang juga membutuhkan persetujuan semua.

Selanjutnya, Habermas menyatakan bahwa untuk mencapai konsensus rasional yang diterima secara umum, diskursus praktis seharusnya bersifat inklusif, egaliter, dan bebas domninasi. Inklusif berarti keikutsertaan di dalam sebuah diskursus hanya mungkin, jika orang mempergunakan Bahasa yang sama dan secara konsisten mematuhi aturan-aturan logis dan semantic dari Bahasa tersebut. Egaliter kesamaan dalam memperoleh kesempatan dalam diskursus hanya dapat terwujud, jika setiap peserta memiliki maksud untuk mencapai consensus yang tidak memihak dan memandang para peserta lainnya sebagai pribadi-pribadi otonom yang tulus, bertanggung jawab, dan sejajar, serta tidak menganggap mereka ini hanya sebagai sarana belaka. Bebas dominasi berarti harus ada aturan-aturan yang dipatuhi secara umum yang mengamankan proses diskursus dari tekanan dan diskriminasi. ${ }^{37}$

Sebagai tujuan diskursus praktis, konsesnsus yang legitim tentang norma-norma yang problematis memerlukan prasyaratprasyarat terntentu yang memungkinkan semua peserta menganggap sah consensus yang mereka hasilkan. Jadi, diskursus praktis di sini mengacu tidak hanya pada proses komunikasi yang ideal, melainkan juga aturan-aturan komunikasi yang ideal yang diformalisasikan dari

\footnotetext{
${ }^{36}$ Ibid., h. 29-35.

${ }^{37}$ Ibid., h. 48-49.
} 
proses komunikasi ideal itu. Habermas berpendapat bahwa sebuah pernyataan atau tindakan seseorang bersifat rasional sejauh alasannya dapat dijelaskan atau diakui secara intersubjektif. Penjelasan dan pemberian alas an adalah ciri dasar dari klaim-klaim kesahihan yang bersifat rasional. Para peserta komunikasi tidak lagi dapat memakai begitu saja pernyataan-pernyataan yang sudah diterima bersama sebagai bagian dari lebenswelt (dunia-kehiduapan), karena komunikasi sekarang telah menjadi reflektif dan menuntut alas anasalan yang bersifat rasional. Para peserta diskursus seakan-akan keluar dari lebelswelt mereka masing-masing untuk menyelesaikan secara rasional masalah-masalah yang mereka ambil dari lebelswelt mereka. ${ }^{38}$

Kesimpulannya, diskursus praktis adalah bentuk refleksi tindakan komukatif. Maksudnya bahwa diskursus praktis adalah kelanjutan tindakan komukatif dengan memakai sarana lain, yaitu sarana argumentatif. Dengan demikian, diskursus praktis menandai bentuk komunikasi modern di mana orang tidak begitu saja menerima sesuatu dengan pemahaman-pemahaman yang berkembang lewat tradisi, melainkan pertama-tama menguji hal itu dengan pertimbangan rasional. Dalam arti ini, diskursus praktis merupakan bentuk komunikasi yang bersifat kritis dan terbuka.

Apabila dibandingkan dan dianalisis dengan menggunakan teori diskursus Habermas, maka hermeneutika Abou El-Fadl belum beranjak dari model diskursus teoritis. Proses penyelidikan hukum dilakukan oleh ahli hukum secara monologal dan tidak membuka dialog dengan komunitas-komunitas interpretasi lainnya. Dengan demikian, keputusan hukum dilakukan oleh subjek tunggal dan tidak melakukan komunikasi saling mengerti dengan subjek-subjek lainnya. Beberapa persyaratan memang telah diajukan oleh Abou ElFadl dalam proses penetapan hukum, seperti adanya lima basis etis dan empat asumsi dasar penafsiran, yang harus dipenuhi oleh para ahli hukum. Tapi semua itu semata-mata dimaksudkan agar para ahli hukum dapat menghasilkan keputusan hukum yang dipandang benar (truth) yang bersifat positivistik. Begitu pula, Abou El-Fadl menyatakan bahwa moralitas tertinggi dalam proses penetapan hukum adalah moralitas diskursus, bukan semata kebenaran atau ketepatannya. Tapi diskursus di sini maksudnya adalah adanya

${ }^{38}$ Ibid., h. 44. 
interaksi dan proses negosiasi yang seimbang antara para ahli hukum dengan pengarang teks dan teks yang sedang ditafsirkan (diskursus teoritis), bukan diskursus untuk mencapai consensus hukum dengan komunitas-komunitas hukum lainnya (diskursus praktis).

Dengan asumsi-asumsi di atas, hermeneutika Abou El-Fadl perlu dikembangkan lebih lanjut dengan mengikuti model-model diskursus praktis. Ini karena ketika seseorang berhubungan dengan lebenswelt (dunia-kehidupan), ia berhadapan secara serentak dengan tiga dunia, yaitu dunia objektif, dunia sosial, dan dunia subjektif. Oleh karena itu, pemahaman hermeneutika harus menggunakan sistem acuan ketiga dunia tersebut sebagai kerangka kerja interpretatif. Paradigma teori komunikasi digunakan di sini, bahwa pengetahuan harus merupakan hasil konsensus dengan subjek-subjek lain dan dipeoleh melalui prosedur atau proses yang diakui secara intersubjektif, bukan oleh seorang subjek secara monologal. Apa yang penting dalam diskursus praktis bukanlah kemasukakalan sebuah klaim dari seorang subjek secara monologal, melainkan prosedur yang diakui secara intersubjektif. Lewat prosedur itulah produkproduk proses rasional memperoleh kesahihannya. Hal ini berarti bahwa sifat rasional tidak dapat dicapai semata-mata oleh seorang subjek tunggal, namun didekat dengan argumentasi rasional dengan subjek-subjek lainnya. Begitu pula, sifat rasional dari sebuah klaim hanya dapat dicapai secara komunikatif melalui prosedur yang tanpa paksaan dan bebas kekuasaan. Hal ini berarti sebuah klaim disebut tidak rasional, jika klaim itu dikeluarkan di bawah paksaan.

Dengan demikian, dalam konteks hukum Islam, hermeneutika deliberatif merupakan sebuah gagasan bagaimana dapat diciptakan ruang public (public sphere) untuk membangun diskursus praktis antarkomunitas interpretasi hukum yang plural. Hermeneutika deliberatif menjamin semua ahli hukum dan berbagai komunitas interpretasi, secara bebas dan tanpa paksaan, terlibat penuh dalam proses penetapan hukum melalui diskursus-diskursus yang terusmenerus dilakukan. Pada akhirnya, proses-proses yang berlangsung secara deliberatif dan diskursif ini merupakan sumber legitimasi bagi setiap keputusan hukum. Lebih-lebih dalam sebuah negara demokrasi, dibutuhkan partisipasi publik umat Islam dalam membentuk sebuah hukum positif. Karena itu, hanya melalui komunikasi dan diskursus antarkomunitas hukum, sumbangan umat 
dalam positivisasi hukum tersebut mungkin untuk diwujudkan. Dengan gagsan ini, hermeneutika Abou El-Fadl diharapkan tidak hanya berkontribusi penting dalam menghasilakn hukum yang benar dalam dirinya sendiri (bersifat positivistik), namun akan menghasilkan hukum yang kebenarannya dapat diterima oleh seluruh umat Islam (bersifat konsensus).

\section{F. Penutup}

Metode heremeneutika Khaled lebih lunak dalam membaca teks-teks keagamaan. Dalam beberapa pandangan, dia sangat mengapresiasi tradisi fikih dalam Islam yang menjunjung tinggi perbedaan dan pada sisi lain dia menggunakan teori-teori Barat yang diinternalisasi dengan cukup kritis. Hermeneutika Abou El-Fadl dapat disebut 'hermeneutika negosiatif'. Menurutnya, makna harus merupakan hasil interaksi antara pengarang, teks, dan pembaca, di mana harus ada keseimbangan (balancing) dan proses negosiasi antara ketiga pihak, serta salah satu pihak tidak boleh mendominasi dalam proses penetapan makna. Dengan demikian, penetapan makna teks selalu melibatkan proses yang kompleks, interaktif, dinamis, dan dialektis antara ketiga unsur dalam lingkungan hermeneutis, yaitu pengarang, teks, dan pembaca. Hermeneutika Abou El Fadl secara implisit mengandung semangat Gadamerian yang membaca teks secara subjektif, implikasinya seluruh interpretasi tidaklah bersifat final namun relatif. Dengan demikian, hermeneutika Abou El Fadl belum memasuki wilayah ilmu kritis yang bersifat emansipatoris, dengan membangun komunikasi dan melakukan diskursus praktis dengan komunitas interpretasi lain dalam rangka menghasilkan pengetahuan Bersama yang disebut diskursus. Dalam kerangka ini, hermeneutika deliberatif merupakan sebuah gagasan bagi terwujudnya diskursus yang inklusif, egaliter, dan bebas dominasi dalam mewujudkan sebuah konsensus. [.]

\section{Daftar Rujukan}

Abdullah, M. Amin. "Pendekatan Hermeneutik dalam Studi Fatwafatwa Keagamaan" dalam pengantar buku Khaled Khaled M. 
Abou el Fadel, Atas Nama Tuhan: dari Fiqih Otoriter ke Fiqih Otoritatif, terj. Cecep Lukman Yasin, (Jakarta: PT Serambi Ilmu Semesta, 2004)

El Fadl, Khaled M. Abou. 2001. Speaking in God's Name: Islamic Law, Authority and Woman. Oxoford: Oneworld Publications.

El Fadl, Khaled M. Abou. 2004. Atas Nama Tuhan: Dari Fikih Otoriter ke Fikih Otoritatif, terj. R. Cecep Lukman Yasin. Jakarta: PT. Serambi Ilmu Semesta.

El Fadl, Khaled Abou. 2007. Selamatkan Islam dari Muslim Puritan, terj. Helmi Mustafa Jakarta: Serambi.

Faiz, Fahruddin. 2005. Hermeneutika al-Quran: Tema-tema Kontroversial. Yogyakarta: eLSAQ.

Gadamer, Hans George. 1975. Truth and Methode. New York: The Seabury Press.

Faiz, Fahruddin. 2002. "Teks, Konteks, Kontekstualisasi (Hermeneutika Modern dalam Ilmu al-Quran Kontemporer)", dalam M. Amin Abdullah, et. al., Tafsir Baru Studi Islam dalam Multikultural. Yogyakarta: IAIN Sunan Kalijaga.

Hardiman, F. Budi. 2009. Kritik Ideologi: Menyingkap Pertautan Pengetahuan dan Kepentingan Bersama Jurgen Habermas. Yogyakarta: Kanisius.

Hardiman, F. Budi. 2015. Seni Memahami: Hermeneutik dari Schleiermacher sampai Derrida. Yogyakarta: Kanisius.

Hardiman, F. Budi. 2009. Demokrasi Deliberatif: Menimbang Negara Hukum dan Ruang Publik dalam Teori Diskursus Jurgen Hubermas. Yogyakarta: Kanisius.

Hidayat, Komaruddin. 2004. Menafsirkan Kehendak Tuhan. Jakarta: Teraju.

Rohmanu, Abid. 2010. Konsepsi Jihad Khaled M. Abou El Fadl dalam Perspektif Relasi Fikih, Akhlak dan Tauhid, Disertasi. Surabaya: IAIN Sunan Ampel.

Sudarto. 1996. Metodologi Penelitian Filsafat. Jakarta: Rajawali Pers.

Suseno, Frans Magnis. 2005. Pijar-pijar Filsafat. Yogyakarta: Kanisius. 